\title{
Effect of ethyl acetate crude extract of Lasiodiplodia pseudotheobromae IBRL OS-64 against oral cavity bacteria with emphasis on Streptococcus mutans
}

\author{
Taufiq M.M.J*, Darah I \\ Industrial Biotechnology Research Laboratory, School of Biological Sciences, Universiti Sains Malaysia, 11800 Minden, Penang, Malaysia.
}

\begin{tabular}{|c|c|}
\hline ARTICLE INFO & ABSTRACT \\
\hline $\begin{array}{l}\text { Received on: } 28 / 02 / 2019 \\
\text { Accepted on: } 13 / 09 / 2019 \\
\text { Available online: } 04 / 11 / 2019\end{array}$ & $\begin{array}{l}\text { Streptococcus mutans and Streptococcus agalactiae have been reported in human oral diseases including caries } \\
\text { and periodontitis. Thus, the present study was performed to investigate the effect of ethyl acetate crude extract of } \\
\text { Lasiodiplodia pseudotheobromae IBRL OS- } 64 \text {, an endophytic fungus isolated from Ocimum sanctum leaf against } \\
\text { S. mutans and S. agalactiae. Disk diffusion and broth microdilution assays were used to determine the antimicrobial }\end{array}$ \\
\hline $\begin{array}{l}\text { Key words: } \\
\text { Streptococcus mutans, } \\
\text { Streptococcus } \\
\text { agalactiae, Lasiodiplodia } \\
\text { pseudotheobromae, } \\
\text { antimicrobial activities, } \\
\text { microscopic analysis. }\end{array}$ & $\begin{array}{l}\text { activities with minimum inhibitory concentration (MIC) and minimum bactericidal concentration (MBC) values. } \\
\text { Meanwhile, the microscopic analysis was used to study the structural degeneration of bacterial cells. The fungal crude } \\
\text { extracts demonstrated favorable antibacterial activity toward both test bacteria and produced an inhibition zone ranging } \\
\text { from } 16.0 \text { to } 21.2 \mathrm{~mm} \text {. The MIC and MBC values of the fungal crude extract toward } S \text {. mutans and } S \text {. agalactiae were } \\
\text { determined and the results showed that the MIC and MBC values were in the range of } 125-500 \mu \mathrm{g} / \mathrm{ml} \text { and } 125-1,000 \\
\mu \mathrm{g} / \mathrm{ml} \text {, respectively. The time-kill study suggested that the ethyl acetate crude extract possessed bactericidal effect } \\
\text { with concentration and time-dependent. Structural degeneration studies revealed the major abnormalities occurred } \\
\text { to } S \text {. mutans cells after treated with the fungal crude extract where completed alterations of their morphology with } \\
\text { the formation of cavities and collapsed cells beyond repair occurred. Therefore, the current study suggested the ethyl } \\
\text { acetate crude extract of } L \text {. pseudotheobromae IBRL OS-64 could be an effective antibacterial agent to treat oral cavity } \\
\text { bacteria. }\end{array}$ \\
\hline
\end{tabular}

\section{INTRODUCTION}

Dental caries is one of the most chronic diseases affecting the human life and considered as one of the most crucial global oral health burdens by World Health Organization (WHO), which affects various age group of people worldwide (Hoceini et al., 2016; Struzycka, 2014). Cariogenic plaques occurred when aciduric and acidogenic bacterial strains increase with the increment frequency of exposure to carbohydrate. Utilizing of carbohydrate by bacterial strains leads to acidification of biofilm which resulted in demineralization of the dental hard tissues (Filoche et al., 2010). Approximately 700 microbial strains have

\footnotetext{
*Corresponding Author

Taufiq M.M.J, Industrial Biotechnology Research Laboratory, School of Biological Sciences, Universiti Sains Malaysia, 11800 Minden, Penang, Malaysia.E-mail: fiqz04@yahoo.com.sg
}

been reported to form oral microbial communities in human where they are nourished with nutrients and provided with a conducive habitat (Kuramitsu et al., 2007; Philip et al., 2009). Moreover, the dental plaques supported oral cavity microbes by providing them a cocoon and they secreted dextran which allows them to bind to the surface of the tooth. Dental plaque is a microbial consortium that is found on the tooth surface as a biofilm which consists of bacterial origin and a matrix of polymers of the host (Marsh, 2004; Socransky and Haffajee, 2002). For decades, Streptococcus mutans is one of a normal community found in the dental plaque and has been considered as a primary causative agent of dental caries. It is capable to adhere to the enamel surface, synthesize extracellular polysaccharides which lead to dental caries and known as a strong acid producer and thus it creates an acidic environment which enhances the risk of cavity formation (Forssten et al., 2010).

Even though there are several antibiotic drugs that can be used to combat oral cavity bacteria, the interest in searching and 
developing new non-toxic antimicrobial compound is increasing due to concern about safety and health. As a result, interest in using natural product or natural antimicrobial compounds has become popular among researchers worldwide. To date, the search for bioactive properties has focused mainly on plant and soil microorganisms. However, an exploration for new biotopes is necessary due to extensively used plant leads to the extinction of some species (Bentley, 2010) and rapid decrease in discovering microorganisms with new metabolites (Guo et al., 2011; Schulz et al., 2002). Endophytes are known as one of the trending sources of the natural bioactive compound and they can be defined as an endosymbiotic group of microbes such as bacteria and fungi that colonize the intra- and intercellular part of the plant (Pimentel et al., 2011; Singh and Dubey, 2015). Endophytes have been reported to enhance the growth of their host by helping in the nutrient uptake and they are also capable to improve host ability to tolerate of various environmental stresses, besides enhancing the resistant to pests and insects. Furthermore, they are able to produce various bioactive compounds with pharmacological interest such as antibiotics and enzymes (Joseph and Priya, 2011; Parthasarathi et al., 2012). Lasiodiplodia is a member of the family Botryosphaeriaceae that has been isolated from more than 1,000 host plants worldwide including native forest trees and commercially important agriculture (Mehl et al., 2013). This genus is frequently reported as a plant pathogen especially in mango all over the world, and also associated with several plant disease symptoms including canker (Urbez-Torres et al., 2008), dieback (Ismail et al., 2012), and decline (Burruano et al., 2008). It is also known as the endophytic fungus that has been isolated from various host plants including mistletoe (Qian et al., 2014), mangroves (Chen et al., 2016), Jatropha curcas L. (Sulaiman et al., 2012), and Piper hispidum (Orlandelli et al., 2015). Secondary metabolites produced by Lasiodiplodia species have been reported to exhibit anticancer (Pandi et al., 2011), anti-inflammatory (Chen et al., 2017), herbicidal (Adetunji and Oloke, 2013), anti-proliferative activity (Alves da Cunha et al., 2012), antibacterial (Wei et al., 2014), and antifungal (Orlandelli et al., 2015) properties. Among the bioactive compounds included lasiodiplines (Alves da Cunha et al., 2012), taxol (Pandi et al., 2011), theobroxide (Li et al., 2007), lasioplodin (Kashima et al., 2009), preussomerins (Chen et al., 2016), and indole-3-carboxylic acid (Qian et al., 2014).

Therefore, the present study is focused mainly on the evaluation of ethyl acetate extract of Lasiodiplodia pseudotheobromae IBRL OS-64 for its activity against oral cavity bacteria, due to its various medicinal potentials.

\section{MATERIAL AND METHODS}

\section{Maintenance of $L$. pseudotheobromae IBRL OS-64}

The fungal endophyte was provided by IBRL, School of Biological Sciences, Universiti Sains Malaysia (USM), Penang, Malaysia. The isolate was cultured on potato dextrose agar nourished with host plant powder $(2 \mathrm{~g} / \mathrm{l})$ and incubated at $30^{\circ} \mathrm{C}$ for 5 days before storing at $4^{\circ} \mathrm{C}$ prior to use. The purity and viability of the fungal isolate were maintained by sub-culturing every month on sterile fresh media.
Culture medium, cultivation, and extraction of extracellular secondary metabolites

Yeast extract sucrose broth, cultivation and extraction process were done according to the method described by Taufiq and Darah (2018).

\section{Culture maintenance of test microorganisms}

Two oral cavity bacteria, $S$. mutans and $S$. agalactiae culture were provided by the IBRL, School of Biological Sciences, Universiti Sains Malaysia, Penang, Malaysia. The bacterial culture was cultured and maintained on brain heart infusion agar (BHIA) and incubated at $37^{\circ} \mathrm{C}$ for 24 hours before storing them at $4^{\circ} \mathrm{C}$ before use. To ensure their purity and viability, the cultures were sub-cultured every month on fresh BHIA slants.

\section{Disk diffusion susceptibility assay}

The assay was carried out as per the procedure described in Clinical and Laboratory Standard Institute standard M100-S16 (Tong et al., 2011) with slight modifications. The experiments were performed in triplicate and the results were expressed as mean value \pm standard error of the inhibition zone obtained from three separated occasions.

\section{MIC and MBC determinations}

The determination of minimum inhibitory concentration (MIC) and minimum bactericidal concentration (MBC) values of the fungal crude extract was performed using broth micro-dilution assay in sterile 96-wells U-shaped microtiter plate as described by Jorgensen and Ferrero (2009) and Tong et al. (2012), respectively, with some modifications.

\section{Time-kill study of $S$. mutans}

Time-kill curve and bacterial cell reduction analysis were carried out according to the method described by Taufiq and Darah (2019) and Ibrahim et al. (2015), respectively. The experiments were conducted in triplicate on separate occasions.

\section{Scanning electron microscopy (SEM) and transmission electron microscopy (TEM)}

Samples were prepared according to the method described by Taufiq and Darah (2019). The specimen preparations for SEM and TEM were performed according to the method described by Mares (1989) and Yogalatha et al. (2011), respectively. The prepared specimens were then viewed under a scanning electron microscope (Leica Cambridge, S-360, United Kingdom) and transmission electron microscope (Philips CM12, Eindhoven, The Netherlands).

\section{Statistical analysis}

Data obtained are presented as means \pm standard deviations (SD) of triplicate. The antibacterial activity of the ethyl acetate crude extract against two oral cavity bacteria was compared by Student $t$-test, using SPSS Version 18.0. Statistical significance was assumed at the 0.05 levels $(p<0.05)$.

\section{RESULTS}

Antibacterial activity of the ethyl acetate crude extract on the oral cavity bacteria is illustrated in Table 1 . The fungal 
crude extract exhibited antibacterial activity with the diameter of inhibition zones ranging from 16.0 to $21.2 \mathrm{~mm}$. Results revealed that $S$. mutans was more susceptible to the fungal crude extract compared to $S$. agalactiae. There were significant differences in the antibacterial activities for both bacterial strains as tested using $t$-test, $(p<0.05)$.

Subsequent experiments were performed to determine MIC and MBC values of the crude extract against the oral cavity bacteria. The susceptibility test results for ethyl acetate crude extract are presented in Table 2. The MIC values ranged between 125 and $500 \mu \mathrm{g} / \mathrm{ml}$, whereas the MBC values ranged between 125 and $1,000 \mu \mathrm{g} / \mathrm{ml}$. The results revealed that ethyl acetate crude extract showed a significant inhibitory effect on $S$. mutans since the MIC and the MBC were in the same values. As for $S$. agalactiae, the $\mathrm{MBC}$ was higher than the MIC values, indicating that the concentration of the fungal extract would have to be increased to kill bacterial cells, instead of inhibiting their growth. However, the results showed that the MBC/MIC ratio was less than four folds which indicated that the fungal crude extract possesses bactericidal effect toward S. mutans and S. agalactiae. The results obtained confirmed the antibacterial potential of the fungal crude extract. Based on the results of disk diffusion susceptibility assay and the MIC value, bacterial strain $S$. mutans was chosen for a subsequent experiment on the time-kill curve

Table 1. Antibacterial activity of the ethyl acetate crude extract of L. pseudotheobromae IBRL OS-64 against oral cavity bacteria

\begin{tabular}{lccc}
\hline \multirow{2}{*}{ Bacterial strains } & \multicolumn{3}{c}{ Zone of inhibition $\mathbf{( m m})$} \\
\cline { 2 - 4 } & $\begin{array}{c}\text { EA* extract } \\
(\mathbf{1} \mathbf{~ m g} / \mathbf{m l})\end{array}$ & $\begin{array}{c}\text { Chloramphenicol } \\
\mathbf{( 3 0} \boldsymbol{\mu g} / \mathbf{m l})\end{array}$ & $\begin{array}{c}\text { Ampicillin } \\
\mathbf{( 3 0} \boldsymbol{\mu g} / \mathbf{m l})\end{array}$ \\
\hline Streptococcus mutans & $21.2 \pm 0.3^{\mathrm{a}}$ & $28.4 \pm 0.3$ & - \\
Streptococcus agalactiae & $16.0 \pm 0.2^{\mathrm{b}}$ & - & $27.2 \pm 0.4$ \\
\hline
\end{tabular}

"EA $=$ ethyl acetate. $* *$ Superscript shows the significant different between two means $(t$-test, $p<0.05)$

Table 2. MIC and MBC of fungal crude extract against oral cavity bacteria.

\begin{tabular}{lccc}
\hline Microorganisms & MIC $(\boldsymbol{\mu g} / \mathbf{m l})$ & MBC $(\boldsymbol{\mu g} / \mathbf{m l})$ & MBC/MIC \\
\hline S. mutans & 125 & 125 & 1 \\
S. agalactiae & 500 & 1000 & 2 \\
\hline
\end{tabular}

as well as the structural degeneration studies through SEM and TEM observations.

Time-kill study of the ethyl acetate extract against oral cavity bacteria, $S$. mutans for 48 hours of the incubation period is shown in Figure 1. Growth control of S. mutans demonstrated a normal growth pattern with four typical growth phases of bacteria, namely, lag, exponential, stationary, and death phases. The bacterial cell experienced a lag phase for the first 4 hours of the incubation period. After that, they undergo an exponential phase up to 28 hours of incubation period with the highest colony count achieved was approximately $1.8 \times 10^{7} \mathrm{CFU} / \mathrm{ml}$. The growth of bacterial cells was then into a stationary phase (up to 38 hours of incubation) and followed by the death phase thereafter.

The growth curve of $S$. mutans which was exposed to $1 / 2$ MIC $(62.5 \mu \mathrm{g} / \mathrm{ml})$ of extracts showed almost a stagnant line with no significant cell growth throughout the 48 hours of the incubation period. The viable cell counts of the bacteria declined gradually in which the lowest number of bacterial cell count recorded was $2.0 \times 10^{4}$ and $2.3 \times 10^{4} \mathrm{CFU} / \mathrm{ml}$, at incubation hours of 32 and 48, respectively. The results indirectly revealed that the fungal extract had not exerted bactericidal effect on the test bacterial cells, $S$. mutans at low concentration such as $1 / 2$ MIC.

Following that, with the addition of MIC $(125.0 \mu \mathrm{g} / \mathrm{ml})$ concentration of the extract, the number of viable cells was gradually declined from the 0 to $20^{\text {th }}$ hour of the incubation period. After that, the growth curve showed a steep decline of the viable cells counts after $20^{\text {th }}$ hour of treatment. Moreover, all S. mutans cells were killed after 40 hours of treatment with the extract without regrowth of bacteria cell throughout the experiment. Besides that, a similar phenomenon was observed when the bacterial culture was treated with double MIC $(250.0 \mu \mathrm{g} / \mathrm{ml})$ concentration in which the number of bacterial cell decreased drastically. However, the higher concentration of extract has rapidly killed the cells up to $99.9 \%$ after 28 hours of the incubation period. Therefore, the results revealed that the fungal crude extract possesses strong bactericidal effect on $S$. mutans without the emergence of new resistance cells and the bactericidal effect of the extract was concentration-dependent.

The killing efficiency of the fungal crude extract on S. mutans is shown in Table 3 with no bacterial cell reduction was

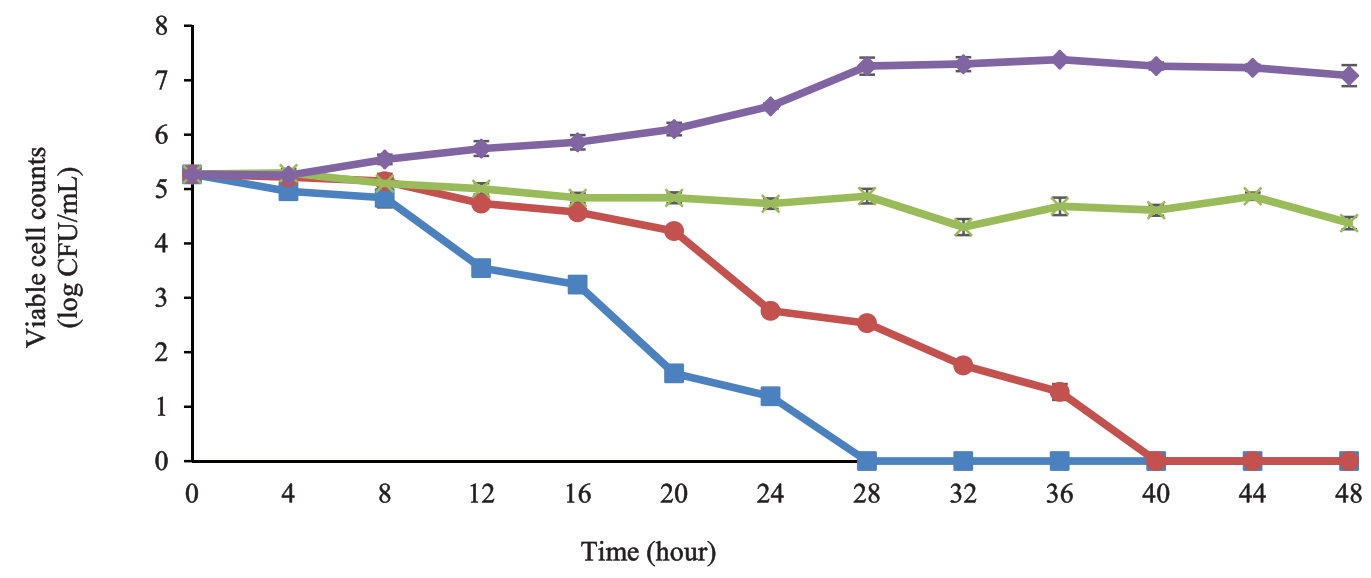

Figure 1. Time-kill curve of fungal crude extract against $S$. mutans at different concentrations. 
Table 3. Reduction in viable $S$. mutans cell counts in the presence of fungal extract at different concentration levels.

\begin{tabular}{ccccc}
\hline $\begin{array}{c}\text { Percentage of } \\
\text { reduction (\%) }\end{array}$ & \multicolumn{4}{c}{ Time (hour) } \\
\cline { 2 - 5 } & Control & $1 / 2$ MIC & MIC & 2 MIC \\
\hline 50 & NR & $4-8$ & $4-8$ & $0-4$ \\
90 & NR & $12-16$ & $8-12$ & $8-12$ \\
99 & NR & NR & $20-24$ & $8-12$ \\
99.9 & NR & NR & $20-24$ & $16-20$ \\
\hline
\end{tabular}

NR: not reach

observed for the growth control. As for $1 / 2$ MIC concentration, $50 \%$ and $90 \%$ reduction of initial inoculum was achieved after (4-8 hours) and (12-16 hours) treated with the extract, respectively. Meanwhile, MIC and $2 \times$ MIC showed growth reduction up to $99.9 \%$ of initial inoculum after an incubation period of 40 and 28 hours, respectively, with double MIC able to shortly kill all the bacterial cells. Overall, the effects exerted by the fungal crude extract were observed through the growth curve of $S$. mutans where the extract was able to reduce the growth of bacterial cell compared to non-treated culture. The results revealed that a longer time of exposure was required to achieve a higher percentage of bacterial growth reduction and higher concentration, the crude extract was also required for the rapid inhibition of all the bacterial cells. Based on the time-kill analysis, it was obviously seen the potency of the ethyl acetate extract of L. pseudotheobromae IBRL OS-64 as antibacterial agents against oral cavity bacteria.

The morphological changes of $S$. mutans cells treated with fungal crude extract for 36 hours are illustrated in Figure 2. Structural degeneration of the bacterial cells at different time intervals (12 hours, 24 hours, and 36 hours) was compared to the treated cells at 0 hour (control). In general, the degree of disruption of $S$. mutans cells was depending on exposure time to fungal extract, whereby the severity of the cell alterations increased with the increment time of exposure. Figure 2a shows the treated control cells appeared as smooth surface of shape and its rigidity with the normal coccal chains. However, changes were observed on the bacterial cells after 12 hours exposure with the fungal crude extract which was indicated by the formation of cavities (Figure 2b).

After 24 hours of the exposure period, more cavities formed and cell debris were observed on the bacterial cells treated with the extract. In fact, some of the $S$. mutans cells started to lyse, shrunk, and collapsed (Fig. 2c). The disruption of the bacterial cells has continuously occurred after 36 hours of incubation period whereby more cavities formed and cell debris were observed. Most of the bacterial cells were lysed, shrunk abruptly, and completely collapsed (Fig. 2d). The normal and smooth coccal chains shape of $S$. mutans was no longer observed but only the crumpled cell residues were left. Overall, the abnormalities of bacterial cells were observed after treating with fungal extract and this destruction could be due to severe alterations indicated by morphological disorganization and invaginations. At this time, the bacterial cells begun to clump together as a quick response to stress condition. Ron (2006) suggested that bacteria were able to secrete sticky mucus under stress condition as part of their responsive mechanisms which led the bacterial cell to clump together which finally affected their normal function.

Morphological and cytological changes of the bacterial cells that were observed under SEM were then further observed under TEM. In general, the effect of the fungal extract was proven to change the morphology and cytology of $S$. mutans cells. Figure 3 exhibits the effect of the ethyl acetate crude extract of $L$. pseudotheobromae IBRL OS-64 against bacterial cells as observed under TEM at different exposure time. Results revealed the intact structures of the cell organelles including nucleus and granules in the cytoplasm.

The dark color of the cell indicated the cytoplasm occupying the cell and the cell was enclosed with a cell wall with uniform thickness. The cell wall of the bacteria was slightly burst indicated by smeared line at a certain part of the cell wall after 12 hours exposure to the fungal extract (Fig. 3a). However, some of the organelles in the cytoplasm were still maintaining their rigidity. Figure $3 \mathrm{~b}$ illustrated the bacterial cells after treated with fungal extract for 24 hours. The photomicrographs clearly showed the cytolysis or cell bursting and leakage of cytoplasm occurred whereby some of the organelles were observed to out-flow. At this point, the invagination of the bacterial cell started and drastically formed. This condition could be due to the metabolism of the fungal extract that prevents the function of organelles inside the cytoplasm. However, some part of the bacterial cell wall was still maintaining their rigidity.

The bacterial cell that was exposed to the fungal extract for 36 hours is shown in Figure $3 \mathrm{~d}$. Results revealed that the bacterial cells were completely collapsed, which are indicated by uniform cell wall formation and loss of their integrity. The organelles inside the cytoplasm were not clearly observed and this may be due to out-flow. Overall, the structural degenerations of $S$. mutans can be observed by the formation of crumpled cells, disintegration of the cell wall, uneven organelles formation, and leakage of cytoplasm that leading to severe cell damage. Thus, the results revealed the effect of ethyl acetate crude extract of L. pseudotheobromae IBRL OS-64 on $S$. mutans cells as an effective and potential antibacterial agent against oral cavity bacteria.

\section{DISCUSSIONS}

The use of the ethyl acetate crude extract of endophytic fungi with antimicrobial activities can be a great significance in the pharmaceutical field. Many endophytic fungi have been studied and utilized due to their antimicrobial properties. The present study showed that the ethyl acetate crude extract of L. pseudotheobromae IBRL OS-64, an endophytic fungus isolated from the leaves of a medicinal plant, Ocimum sanctum possesses a promising antibacterial activity against oral cavity bacteria. This medicinal plant was selected as a host plant to isolate endophytic fungi since it is widely used in the traditional treatment (Pattanayak et al., 2010). The selection of organic solvent for extraction is crucial since it can influence the presence of bioactive substances in the extracts and might affect its activity (Kandasamy and Arunachalam, 2008). Therefore, several organic solvents were used to extract fermentative broth and the results revealed that the ethyl acetate was the best organic solvent (data not shown). Current result was in agreement with the previous studies that employed ethyl acetate as organic solvent in order to obtain bioactive 

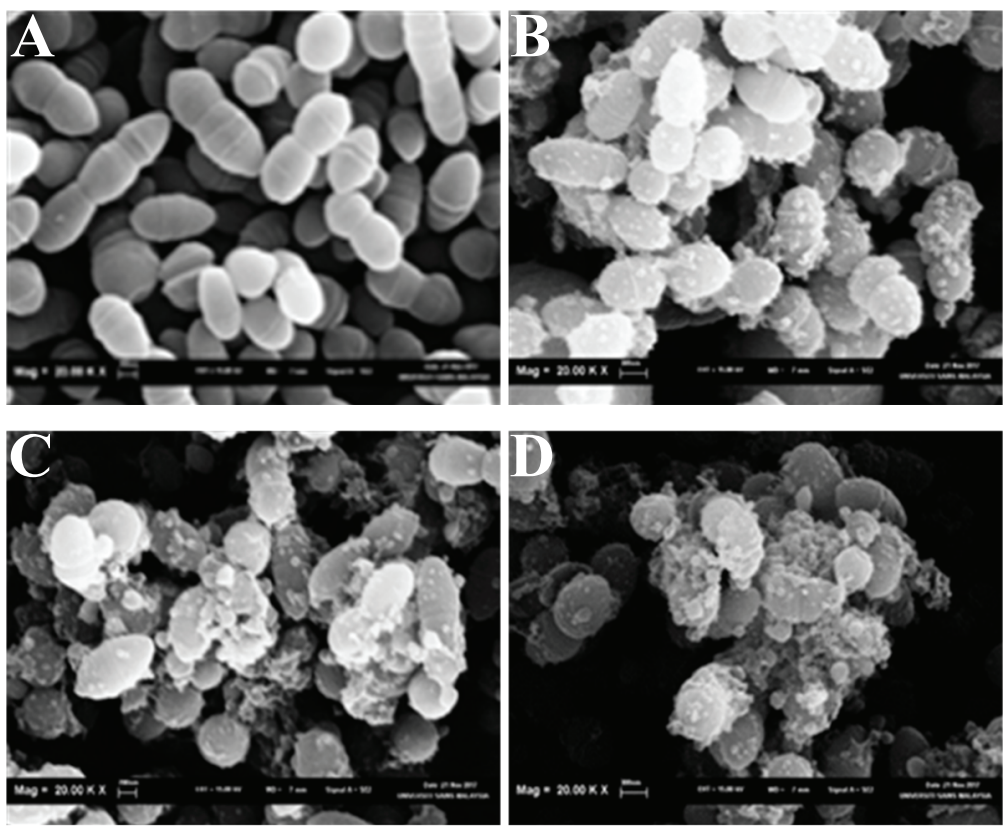

Figure 2. SEM micrographs of $S$. mutans treated with $1 \mathrm{mg} / \mathrm{ml}$ of $L$. pseudotheobromae IBRL OS-64 ethyl acetate extract at different time of exposure. (a) 0 hour [control], (b) 12 hours, (c) 24 hours, and (d) 36 hours. Scale bars: $200 \mathrm{~nm}$.
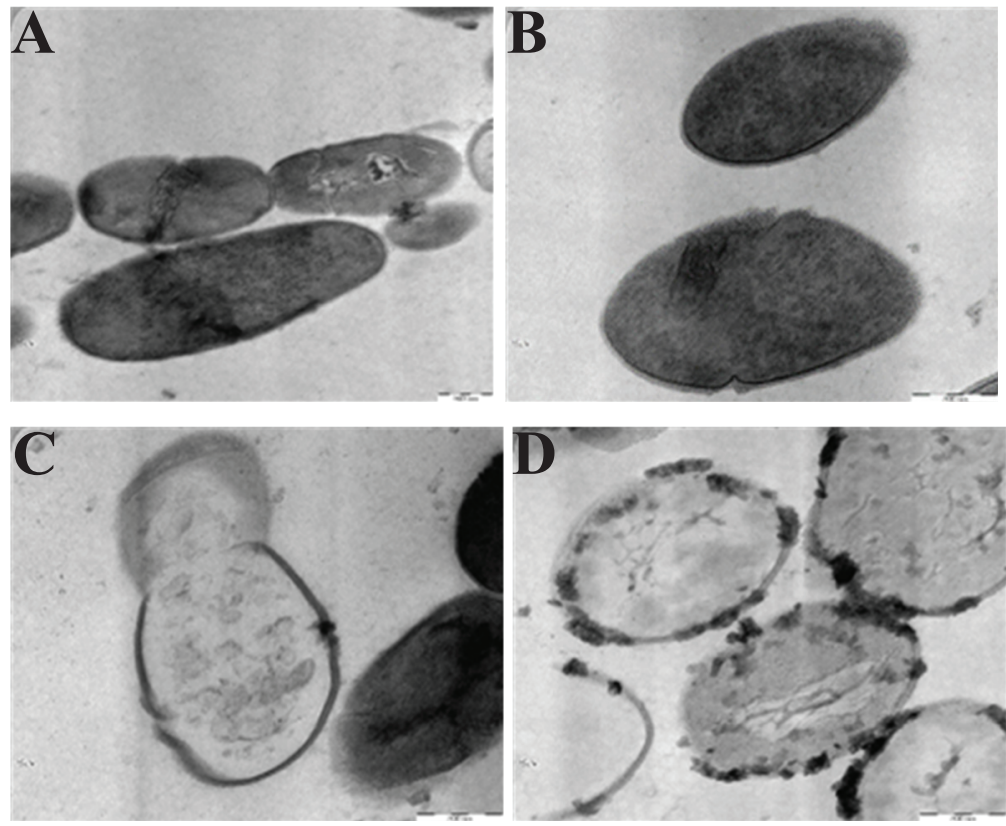

Figure 3. TEM micrographs of $S$. mutans treated with $1 \mathrm{mg} / \mathrm{ml}$ of $L$. pseudotheobromae IBRL OS-64 ethyl acetate extract at different time of exposure. (a) 0 hour [control], (b) 12 hours, (c) 24 hours, and (d) 36 hours. Scale bars: $200 \mathrm{~nm}$.

compounds produced by endophytic fungi (Pongcharoen et al., 2008). Moreover, most antimicrobial compounds exist in nature as mid-polar substances and therefore, they can be extracted using dichloromethane and ethyl acetate (Tong et al., 2014).

The current findings revealed that the $S$. agalactiae was less susceptible to the extract than $S$. mutans and we suspected this phenomenon is caused by the mechanism of drug resistance and antibiotic inactivation enzyme. Previous studies reported the resistant of $S$. agalactiae toward erythromycin due to efflux pump mediated by mefA genes and ribosomal modification encoded by erm genes (Arpin et al., 1999). Besides that, mechanism of antibiotic inactivation enzyme such as O-adenyltransferases and $\mathrm{N}$-acetyltransferases encoded by gene ant and aac, respectively, resulted in high resistance level of $S$. agalactiae toward 
aminoglycosides (Poyart et al., 2003). It is also noteworthy that the current study of $S$. agalactiae strain showed resistance mechanism toward chloramphenicol whereby its growth was not inhibited by the antibiotic. Morici et al., (2017) suggested that chloramphenicol resistance mechanism might be due to a new mosaic integrative and conjugative element produced by $S$. agalactiae strains that carrying the resistance genes known as catQ.

The effect of the crude fungal extract toward $S$. mutans and $S$. agalactiae can be considered as bactericidal due to low ratio of MBC/MIC. According to Levison (2000), the MBC value was not more four-fold higher than their MIC value for bacterial drugs. On disk diffusion assay, the fungal crude extract produced a larger diameter of clear zone toward $S$. agalactiae but did not show lower MBC values. This may be due to the capability and rate of the crude extract to diffuse through the disk as well as the depth of agar medium. The difference results obtained in MBC values and the diameter of clear zones may be due to the diffusion of smallor medium-sized polar compound (Tong et al., 2014). In addition, the rate of extract diffusion and hydrophobicity of the bioactive compounds were also affect the diameter of the clear zone in disk diffusion assay (Thamlikitkul et al., 2008). Meanwhile, Scorzoni et al. (2007) suggested that non-polar antimicrobial compounds and volatile compounds such as sequesterpene cannot easily diffuse into the agar and the disk diffusion assay was not suitable to be implemented. Silva et al. (2005) reported if a mixture constituent of bioactive compounds was applied on disk diffusion, the different rate of diffusion may occur and the result might be unreliable. Besides that, Barry (1991) reported that the depth of the agar medium also influence the diameter of inhibition zone whereby in relatively thin agar, the downward diffusion of the fungal extract was limited and the outward diffusion becomes rapid resulting in a "false positive" result with larger of inhibition zone. Therefore, the broth microdilution assay as more sensitive as compared to disk diffusion assay and it provides more information regarding on relative degree of susceptibility of bacteria to the natural products (Luber et al., 2003).

Time-kill curve has been used to investigate tremendous antimicrobial agents. It is a flexible alternative approach that provides more dynamic information regarding on relationship effect of concentration over the time of antimicrobial agents (Nunart et al., 2017). This approach was frequently used as the basis in the investigation of pharmacodynamics drug interactions and it provides descriptive information on the pharmacodynamics of antimicrobial drugs (Tam et al., 2005). The antimicrobial effect of various extract concentrations levels can be directly compared over a wide range of concentrations and times through this approach (Mueller et al., 2004). To the best of authors' knowledge, this is the first research regarding on the in vitro activity of ethyl acetate crude extract of L. pseudotheobromae IBRL OS-64, an endophytic fungus that was isolated from the medicinal herb. The time-kill curve of control showed the bacterial growth exponentially until reaching maximum bacterial concentration at the stationary stage. As for the lowest extract concentration $(1 / 2 \mathrm{MIC})$, the reduction of bacterial was observed in the first 4 hours of exposure and the re-growth occurred. The result was consistent with the previous study in the bacterial kill-time curve of tedizolid (Nunart et al., 2017). At low extract concentration, the post-antibiotic effect might occur whereby the remaining bacteria would begin to resume their growth. Biphasic killing curve with A decline in killing rate over the time was observed when bacterial cells were exposed to a lower concentration of extract, indicating the presence of persister which less susceptible to antimicrobial drugs (Nielsen et al., 2007). The regrowth phenomenon was attributed to two distinct sub-populations with different susceptibility in which the selective growing of resistant sub-population take over the preferential killing of the susceptible sub-population at a specified time of interaction (Tam et al., 2005).

In the current study, the SEM and TEM photomicrograph's views clearly demonstrated the inhibitory effects of the fungal extract on S. mutans. SEM study showed that the fungal extract induced the formation of blebs on the surface of bacterial cells. Similar observations were reported by Hartmann et al. (2010). The formation of blebs or vesicle-like structures could be suggested as antibiotic resistance mechanism of $S$. mutans toward fungal extract. Membrane vesicles enclosed eDNA which is one of the crucial major components in biofilm formation and acts as a cell to cell communications in several bacteria including $S$. mutans (Tashiro et al., 2017). However, these vesicles could be used by fungal extract to counterpart the bacterial cell since it can be a target site for antibiotics. The abnormal cell would be inherited through cell communications and thus, resulted in the disintegration of bacterial membrane cell which leads to cell death. Besides that, Hyde et al. (2006) suggested that morphological changes of the bacteria cells exposed to antibiotic occur when the antimicrobial agent attacked the cell membrane. The present study revealed that the bioactive substance of the ethyl acetate extract attached on the cell surface structure had permeabilized the cell membranes and any abnormalities occur in cell wall integrity would have a tremendous influence on bacterial growth. This prediction was in agreement with Ibrahim et al. (2013) who reported the inhibitory effect of crude methanolic extract from Phyllanthus niruri on the bacteria's cell wall which leads to the complete damage to the cells. As shown by TEM photomicrographs, the irregular shape, loss of integrity, and the leakage of bacterial cells due to extensive loss of organelles in cytoplasm, damage of cell envelope, the initiation of cell's autolytic mechanisms, and removal of crucial ions and molecules (Ibrahim et al., 2015). Black (2008) suggested that a cell with abnormalities such as non-rigid and nonsturdy usually tends to burst when exposed to the low osmotic pressure that leads to cell leakage. Thus, these unstable cells were collapsed beyond repair and resulted in bacterial cell death. Therefore, the present study clearly showed that an endophytic fungus, L. pseudotheobromae IBRL OS-64 isolated from the medicinal herb, $O$. sanctum possesses antibacterial activity against cariogenic bacteria, $S$. mutans. The fungal extract was proven to be bactericidal at higher concentration and could be a resource in the development of therapeutically natural products.

\section{CONCLUSION}

In summary, the present study confirms that the antibacterial potential of the extract of the endophytic fungus, L. pseudotheobromae IBRL OS-64. The fungal crude ethyl acetate extract is proven to be an antibacterial agent for oral cavity bacteria, $S$. mutans. Furthermore, it may have the potential for dental caries treatment although this use will require additional investigation. However, it is important to point out that crude extract such as this 
needs to be further purified to obtain pure active substance(s) and its individual antibacterial activity analysis can be suggested on the basis of the present study.

\section{ACKNOWLEDGMENTS}

The authors are thankful to Universiti Sains Malaysia (USM), Penang for awarding the RUI research grant scheme (ac: 1001/PBIOLOGI/811326) to support this study and Ministry of Education, Malaysia for granting the MyBrain15 scholarship to Taufiq MMJ during his PhD study.

\section{REFERENCES}

Adetunji CO, Oloke JK. Effect of wild and mutant strain of Lasiodiplodia pseudotheobromae mass produced on rice bran as a potential bioherbicide agent for weeds under solid state fermentation. J Appl Biol Biotechnol, 2013; 1(2):018-023.

Alves da Cunha MA, Turmina JA, Ivanov RC, Barroso RR, Marques PT, Fonseca EA, et al. Lasiodiplodan, an exocellular $(1 \rightarrow 6)-\beta$ D: -glucan from Lasiodiplodia theobromae MMPI: production on glucose, fermentation kinetics, rheology and anti-proliferative activity. J Ind Microbiol Biotechnol, 2012; 39(8):1179-88.

Arpin C, Daube H, Tessier F, Quentin C. Presence of mefA and mefE genes in Streptococcus agalactiae. Antimicrob Agents Chemother, 1999; 43:944-6.

Barry AL. 1991. Procedures and theoretical considerations for testing antimicrobial agents in agar media. In: Barry AL (ed.). Antibiotics in laboratory medicine. 3rd edition, The Williams \& Wilkins Co., Baltimore, MD.

Bentley R. 2010. Medicinal plants. In: Bentley R (ed.). DomvilleFife Press, London, UK, pp 23-46.

Black JG. Microbiology, In: Black JG (ed.). Principles and exploration. John Wiley and Sons, Hoboken, NJ, 54-68, 2008.

Burruano S, Mondello V, Conigliaro G, Alfonzo A, Spagnolo A, Mugnai L. Grapevine decline in Italy caused by Lasiodiplodia theobromae. Phytopathol Mediterr, 2008; 47:132-6.

Chen S, Chen D, Cai R, Cui H, Long Y, Lu Y, Li C, She Z. Cytotoxic and antibacterial preussomerins from the mangrove endophytic fungus Lasiodiplodia theobromae ZJ-HQ1. J Nat Prod, 2016; 79:2397-402.

Chen S, Liu Z, Liu H, Long Y, Chen D, Lu Y, She Z. Lasiodiplactone A, a novel lactone from the mangrove endophytic fungus Lasiodiplodia theobromae ZJ-HQ1. Org Biomol Chem, 2017; 15(30):6338-41.

Filoche S, Wong L, Sissons CH. Oral biofilm: emerging concepts in microbial ecology. J Dent Res, 2010; 89:8-18.

Forssten SD, Bjrklund M, Ouwehand AC. Streptococcus mutans, caries and simulation models. Nutrients, 2010; 2(3):290-8.

Guo Z, Hua R, Bai Y, Wu X, Cao H, Li X, Wu X, Tang J. Screening and evaluation of antiphylopathogenic activity of endophytic fungi from live foliages of Ginkgo biloba L. Afr J Microbiol Res, 2011; 5:1686-90.

Hartmann M, Berditsch M, Hawecker J, Ardakani MF, Gerthsen D, Ulrich AS. Damage of the bacterial cell envelope by antimicrobial peptides gramicidin S and PGLa as revealed by transmission and scanning electron microscopy. Antimicrob Agents Chemother, 2010; 54:3132-42.

Hyde AJ, Parisot J, McNichol A, Bonev BB. Nisin-induced changes in Bacillus morphology suggest a paradigm of antibiotic action. Proc Nat Acad Sci USA, 2006; 103:19896-901.

Hoceini A, Khelil NK, Ben-Yelles I, Mesli A, Ziouani S, Ghellai L, Aissaoui N, Nas F, Arab M. Caries-related factors and bacteria composition of supragingival plaque in caries free and caries active Algerian adults. Asian Pac J Trop Biomed, 2016; 6(8):720-6.

Ibrahim D, Hong LS, Kuppan N. Antimicrobial activity of crude methanolic extract from Phyllanthus niruri. Nat Prod Commun, 2013; $8(4): 493-6$
Ibrahim D, Lee CC, Yenn TW, Zakaria L, Sheh-Hong L. Effect of the extract of endophytic fungus, Nigrospora sphaerica CL-OP 30, against the growth of Methicillin-Resistant Staphylococcus aureus (MRSA) and Klebsiella pneumoniae cells. Trop J Pharm Res, 2015; 14(11):2091-7.

Ismail AM, Cirvilleri G, Pollizzi G, Crous PW, Groenewald JZ, Lombard L. Lasiodiplodia species associated with dieback disease of mango (Mangifera indica) in Egypt. Australas Plant Pathol, 2012; 41:649-60.

Jorgensen JH, Ferrero MJ. Antimicrobial susceptibility testing: a review of general principles and contemporary practices. Clin Infect Dis, 2009; 49(11):1749-55.

Joseph B, Priya RM. Bioactive compounds from endophytes and their potential in pharmaceutical effect: a review. Am J Biochem Mol Biol, 2011; 1:291-309.

Kandasamy M, Arunachalam KD. Evaluation of in vivo antibacterial property of seaweeds of south-east cost of India. Afr J Biotechnol, 2008; 7:1958-61.

Kashima T, Takashi K, Matsuura H, Nabeta K. Biosynthesis of resorcylic acid lactone lasiodiplodin in Lasiodiplodia theobromae. Biosci Biotechnol Biochem, 2009; 73(5):1118-22.

Kuramitsu HK, He X, Lux R, Anderson MH, Shi W. Interspecies interactions within oral microbial communities. Microbiol Mol Biol Rev, 2007; 71(4):653-70.

Levison ME. Pharmacodynamics of antibacterial drugs. Infect Dis Clin North Am, 2000; 14:281-91.

Li P, Takei R, Takashi K, Nabeta K. Biosynthesis of theobroxide and its related compounds, metabolites of Lasiodiplodia theobromae. Phytochemistry, 2007; 68(6):819-23.

Luber P, Wagner J, Hahn H, Bartelt E. Antimicrobial resistance in Campylobacter jejuni and Campylobacter coli strains isolated in 1991 and 2001-2002 from poultry and humans in Berlin, Germany. Antimicrob Agents Chemother, 2003; 47(12):3825-30.

Mares D. Electron microscopy of Microsporum cookie after in vitro treatment with protoanemonin: A combined SEM and TEM study. Mycopathologia, 1989; 108:37-44.

Marsh PD. Dental plaque as a microbial biofilm. Caries Res, 2004; 38:204-11.

Mehl JWM, Slippers B, Roux J, Wingfield MJ. Cankers and other diseases caused by the Botryosphaeriaceae. Infect Forest Dis, 2013; 298-317.

Morici E, Simoni S, Brenciani A, Giovanetti E, Varaldo PE, Mingoia M. A new mosaic integrative and conjugative element from Streptococcus agalactiae carrying resistance genes for chloramphenicol (catQ) and macrolides [mef(I) and erm(TR)]. J Antimicrob Chemother, 2017; 72:64-7.

Mueller M, Pena A, Derendorf H. Issues in pharmacokinetics and pharmacodynamics of anti-infective agents: kill curves versus MIC. Antimicrob Agents Chemother, 2004; 48:369-77.

Nielsen EI, Viberg A, Lowdin E, Cars O, Karisson MO, Sandström M. Semimechanistic pharmacokinetic/ pharmacodynamic model for assessment of activity of antimicrobial agents for time-kill curve experiments. Antimicrob Agents Chemother, 2007; 51:128-36.

Nunart T, Chatsuwan T, Treyaprasert W. Time-kill study of the in vitro antimicrobial activity of tedizolid against methicillin resistant Staphylococcus aureus. Thai J Pharma Sci, 2017; 41:25-9.

Orlandelli RC, Almeida TT, Alberto RN, Polonio JC, Azevedo JL, Pamphile JA. Antifungal and proteolytic activities of endophytic fungi isolated from Piper hispidum Sw. Braz J Microbiol, 2015; 46(2):359-66.

Pandi M, Kumaran RS, Choi YK, Kim HJ, Muthumary J. Isolation, and detection of taxol, an anticancer drug produced from Lasiodiplodia theobromae, an endophytic fungus of the medicinal plant Morinda citrifolia. Afr J Biotechnol, 2011; 10:1428-35.

Parthasarathi S, Sathya S, Bupesh G, Samy DR, Mohan MR, Selva GK. Isolation and characterization of antimicrobial compound 
from marine Streptomyces hygroscopicus BDUS 49. WJFMS, 2012; $4: 268-77$.

Pattanayak P, Behera P, Das D, Panda SK. Ocimum sanctum Linn. A reservoir plant for therapeutic applications: an overview. Pharmacogn Rev, 2010; 4(7):95-105.

Philip K, Malek SNA, Sani W, Shin SK, Kumar S, Lai HS, Serm LG, Rahman SNSA. Antimicrobial activity of some medicinal plants from Malaysia. Am J Appl Sci, 2009; 6(8):1613-1617.

Pimentel MR, Molina G, Dionisio AP, Marostica MR, Pastore GM. The use of endophytes to obtain bioactive compounds and their application in biotransformation process. Biotechnol Res Int, 2011; 576286. DOI: $10.4061 / 2011 / 576286$

Pongcharoen W, Rukachairisikul V, Phongpaichit S, Kuhn T, Pelzing M, Sakayaroj J, Taylor WC. Metabolites from the endophytic fungus Xylaria sp. PSU-D14. Phytochemistry, 2008; 69:1900-2.

Poyart C, Jardy L, Quesne G, Berche G, Trieu-Cuot P. Genetic basis of antibiotic resistance in Streptococcus agalactiae strains isolated in a French hospital. Antimicrob Agents Chemother, 2003; 47:794-7.

Qian CD, Fu YH, Jiang FS, Xu ZH, Cheng DQ, Ding B, Gao CX, Ding ZS. Lasiodiplodia sp. ME4-2, an endophytic fungus from the floral parts of Viscum coloratum, produces indole-3-carboxylic acid and other aromatic metabolites. BMC Microbiol, 2014; 14:297. doi:10.1186/ s12866-014-0297-0.

Ron EZ. Bacterial stress response. In: Ron EZ (ed.). The Prokaryotes. Springer, New York, pp 1012-27, 2006.

Schulz B, Boyle C, Draeger S, Rommert AK, Krohn K. Endophytic fungi: a source of novel biologically active secondary metabolites. Mycol Res, 2002; 106:996-1004.

Scorzoni L, Benaducci T, Almeida AMF, Silva DHS, Bolzani VS, Mendes-Giannini MJS. Comparative study of disk diffusion and microdilution methods for evaluation of antifungal activity of natural compounds against medical yeasts Candida spp and Cryptococcus sp. Rev Cienc Farm Basica Apl, 2007; 28(1):25-34.

Silva MTG, Simas SM, Batista TGFM, Cardarelli P, Tomassini TCB. Studies on antimicrobial activity, in-vitro, of Physalis angulata L. (Solanaceae) fraction and physalin B bringing out the importance of assay determination. Mem Inst Oswaldo Cruz, 2005; 100(7):779-82.

Singh R, Dubey AK. Endophytic actinomycetes as emerging source for therapeutic compounds. Indo Glob J Pharm Sci, 2015; 5:106-16.

Socransky SS, Haffajee AD. Dental biofilms: difficult therapeutic targets. J Periodontol, 2002; 28:12-55.

Struzycka I. The oral microbiome in dental caries. Pol J Microbiol, 2014; 63(2):127-35.

Sulaiman R, Thanarajoo SS, Kadir J, Vadamalai G. First report of Lasiodiplodia theobromae causing stem canker of Jatropha curcas in Malaysia. Plant Dis, 2012; 96:767. doi:10.1094/pdis-06-11-0482-pdn

Tam VH, Schilling AN, Nikolaou M. Modelling time-kill studies to discern the pharmacodynamics of meropenem. J Antimicrob Chemother, $2005 ; 55: 699-706$
Tashiro Y, Hasegawa Y, Shintani M, Takaki K, Ohkuma M, Kimbara K, Futamata $\mathrm{H}$. Interaction of bacterial membrane vesicles with specific species and their potential for delivery to target cells. Front Microbiol, 2017; 8:571. doi:10.3389/fmicb.2017.00571

Taufiq MMJ, Darah I. Anti-MRSA of the ethyl acetate crude extract from Lasiodiplodia pseudotheobromae IBRL OS-64, an endophytic fungus isolated from leaf of Ocimum sanctum Linn. Int J Pharm Pharm Sci, 2018; 10(8): 50-5.

Taufiq MMJ, Darah I. Antibacterial activity of an endophytic fungus Lasiodiplodia pseudotheobromae IBRL OS-64 residing in leaves of a medicinal herb, Ocimum sanctum Linn. J App Biol Biotech. 2019;7(02):3541. doi:10.7324/JABB.2019.70207

Thamlikitkul V, Tiengrim S. Effect of different Mueller-Hinton agars on tigecycline disc diffusion susceptibility for Acinetobacter spp. J Antimicrob Chemother, 2008; 62(4):847-8.

Tong WY, Chong CL, Darah I, Latiffah Z. Enhancement of anticandida activity of endophytic fungus Phomopsis sp. ED2, isolated from Orthosiphon stamineus Benth, by incorporation of host plant extract in culture medium. J Microbiol, 2012; 50:581-5.

Tong WY, Darah I, Latiffah Z. Antimicrobial activities of endophytic fungal isolates from medicinal herb Orthosiphon stamineus Benth. J Med Plants Res, 2011; 5(5):831-6.

Tong WY, Nurul JZ, Nurhaida, Tan WN, Melati K, Latiffah Z, Ibrahim D. Antimicrobial activity of Phomopsis sp. ED2 residing in medicinal plant Orthosiphon stamineus Benth. Annu Res Rev Biol, 2014; 4(9):1490-501.

Urbez-Torres JR., Leavitt GM., Guerrero JC, Guevara J, Gubler WD. Identification and pathogenicity of Lasiodiplodia theobromae and Diplodia seriata, the causal agents of bot canker disease of grapevines in Mexico. Plant Dis, 2008; 92:519-29.

Wei W, Jiang N, Mei YN, Chu YL, Ge HM, Song YC, Ng SW, Tan RX. An antibacterial metabolite from Lasiodiplodia pseudotheobromae F2. Phytochemistry, 2014; 100:103-9.

Yogalatha L, Darah I, Jain K, Sashidharan S. Effects of Vernonia cinerea methanol extract on growth and morphogenesis of Candida albicans. Eur Rev Med Pharm Sci, 2011; 15:543-9.

How to cite this article:

Taufiq MMJ, Darah I. Effect of ethyl acetate crude extract of Lasiodiplodia pseudotheobromae IBRL OS-64 against oral cavity bacteria with emphasis on Streptococcus mutans. J Appl Pharm Sci, 2019; 9(11):078-085. 